\title{
Efficient Removal of Ni(II) from Aqueous Solution by Date Seeds Powder Biosorbent: Adsorption Kinetics, Isotherm and Thermodynamics
}

\author{
Abubakr Elkhaleefa ${ }^{1,2} \mathbb{C}^{-}$, Ismat H. Ali ${ }^{3, *(\mathbb{D}}$, Eid I. Brima ${ }^{3,4} \mathbb{C}^{\text {, A. B. Elhag }}{ }^{5,6}$ \\ and Babiker Karama ${ }^{7}$ \\ 1 Department of Chemical Engineering, College of Engineering, King Khalid University, \\ Abha 61413, Saudi Arabia; amelkhalee@kku.edu.sa \\ 2 Department of Chemical Engineering and Chemical Technology, University of Gezira, \\ Wadmedani 21113, Sudan \\ 3 Department of Chemistry, College of Science, King Khalid University, Abha 61413, Saudi Arabia; \\ ebrima@kku.edu.sa \\ 4 School of Allied Health Science, De Montfort University, The Gateway, Leicester LE1 9BH, UK \\ 5 Department of Civil Engineering, College of Engineering, King Khalid University, Abha 61413, Saudi Arabia; \\ abalhaj@kku.edu.sa \\ 6 Department of Geology, Faculty of Science, Kordofan University, Elobied 51111, Sudan \\ 7 Department of Chemical Engineering, Karary University, Khartoum 14411, Sudan; babikerka@hotmail.com \\ * Correspondence: ihali@kku.edu.sa
}

Received: 20 July 2020; Accepted: 14 August 2020; Published: 17 August 2020

\begin{abstract}
Adsorption investigations in batch approaches were performed to explore the biosorption of $\mathrm{Ni}(\mathrm{II})$ ions from aqueous solutions on date seeds powder. The effects of $\mathrm{pH}$, particle size, initial concentration of $\mathrm{Ni}$ (II) ions, adsorbent mass, temperature, and contact on the adsorption efficacy were studied. The maximum removal obtained was $90 \%$ for an original $\mathrm{Ni}$ (II) ion solution concentration of $50 \mathrm{ppm}$ was attained at $\mathrm{pH} 7$ after $30 \mathrm{~min}$ and with $0.30 \mathrm{~g}$ of an added adsorbent. The four adsorption models, namely Freundlich, Langmuir, Dubinin-Radushkevich (D-R), and Temkin were examined to fit the experimental findings. The adsorption system obeys the Freundlich model. The system was found to follow the pseudo-second order kinetic model. Thermodynamic factors; entropy $\left(\Delta \mathrm{S}^{\circ}\right)$, enthalpy $\left(\Delta \mathrm{H}^{\circ}\right)$, and Gibbs free energy $\left(\Delta \mathrm{G}^{\circ}\right)$ changes were also assessed. Results proved that adsorption of $\mathrm{Ni}(\mathrm{II})$ ions is exothermic and spontaneous. Sticking probability value was found to be less than unity, concluding that the process is dominated by physical adsorption.
\end{abstract}

Keywords: adsorption; date seeds; kinetics; isotherm; thermodynamics

\section{Introduction}

The presence of heavy metals in water streams is among one of the most dangerous environmental problems arising from the disposal of untreated industrial effluents [1-4]. Many industries comprise of final treatment processes where discharged metal compounds may lead to pollution in the effluent water $[2,5,6]$. Most of these heavy metals are non-biodegradable or with long biological half-life leading to potential accumulation and human exposure through food or water [1].

$\mathrm{Ni}(\mathrm{II})$ ions exist naturally in water as nitrates, sulfides, and oxides. Nickel intake above the permissible limit causes skin dermatitis, fibrosis, vomiting, pulmonary, nausea, and many other diseases [3,6-9]. Most of the methods used for $\mathrm{Ni}$ (II) removal from artificial wastewater-like cation exchange and precipitation are costly and produce toxic sludge [2,9]. Recently, some economical, renewable, and effective agricultural and natural materials have been studied as alternative biosorbents [2]. 
Date (Phoenix dactylifera) seeds, which are composed of lignin, hemicellulose, and cellulose are effective biosorbents; thus, eliminates various contaminants from wastewater $[4,10]$. The efficiency of this inexpensive biosorbent is due to oxygenated functional groups in the lignocellulosic materials such as cellulose and phenolic compounds [10]. The removal of $\mathrm{Ni}$ (II) ions onto bentonite/grapheme oxide was previously studied [11] and the results revealed that it follows Langmuir isotherm with high uptake capacity. Mehrmad et al. [12] have reported that the removal of $\mathrm{Ni}(\mathrm{II})$ ions by functionalized henna powder depends on the experimental circumstances, mainly the $\mathrm{Ni}$ (II) concentration, the biosorbent mass, and the $\mathrm{pH}$ of the medium, the Freundlich and Langmuir isotherm models were used to define the process. The kinetic data were fitted with the pseudo-second-order reaction. The adsorption of $\mathrm{Ni}(\mathrm{II})$ ions from wastewater by natural clay had previously been investigated [13] and it was reported that the process is controlled by the $\mathrm{pH}$ value of the medium; the sorption process was rapid whereas the maximum adsorption capacity had been attained within $120 \mathrm{~min}$ and it was found that the system follows a pseudo-second-order reaction.

The adsorbent used in this study was prepared by a direct, facile, and economic technique. The process does not require any chemicals addition nor high-temperature calcination. It is believed that only few adsorbents were tested without any modification in the removal of heavy metals from aqueous solutions while being powerfully recyclable. Phoenix dactylifera is one of the most plentiful plants in Saudi Arabia and the region. Using date seed powder as an adsorbent for $\mathrm{Ni}$ (II) ions is considered the novelty of this research.

This work aims to assess the potential of date seed powder to act as an inexpensive and environment-friendly material for the removal of $\mathrm{Ni}$ (II) from artificial wastewater. This study was designed to assess, compare, and characterize the adsorption of $\mathrm{Ni}(\mathrm{II})$ ions by date seeds powder (DSP) without the addition of any chemicals or thermal treatment. DSP was initially characterized using Brunauer-Emmett-Teller (BET) surface area, scanning electron microscope technique (SEM), and attenuated total reflection-Fourier transform infrared spectrometer (ATR-FTIR). The factors that influence the adsorption efficiency such as mass, concentration of $\mathrm{Ni}(\mathrm{II})$ ion, $\mathrm{pH}$, temperature, and contact time, were investigated in this work.

\section{Materials and Methods}

\subsection{Collection and Treatment of Adsorbent}

Dates seeds were collected locally from Abha city, Saudi Arabia. Seeds were rinsed with tap water and then by deionized water, dried at room temperature and were then grounded to powder size using a ball mill before being sieved. The efficiency of the room-temperature dried DSP was compared with small amount of oven-dried DSP and no differences were noticed on the results. Thus, to minimize the cost, drying of DSP by oven was not used in this study.

\subsection{Reagents}

Deionized water ( $>18 \Omega / \mathrm{cm}$, Milli-Q) was used throughout this work for the solutions and DSP preparations. A stock solution of $1000 \mathrm{ppm} \mathrm{Ni}(\mathrm{II})$ ions was prepared using $\mathrm{NiNO}_{3}$ (LOBA Chemie, Laboratory Reagents and fine Chemicals, Mumbai, India).

\subsection{Batch Adsorption}

Adsorption batch experiments were conducted at different operating conditions ( $\mathrm{pH}$, time, adsorbent dosage, adsorbent particles size, and temperature) by adding the desired amount of DSP to $50 \mathrm{~mL}$ of $\mathrm{Ni}$ (II) ion solution under each particular condition. $\mathrm{NaOH}(0.25 \mathrm{M})$ and/or $\mathrm{HCl}(0.25 \mathrm{M})$ were used to control the $\mathrm{pH}$ value. Mechanical thermostated shaker (WSB, Witeg, Belrose, Germany) was used throughout all the experiments. The solutions were filtered and then analyzed using Atomic 
Absorption Spectroscopy (AAS) (SpectrAA 220, Varian, Australia) to measure the remaining Ni(II) ions concentrations. The removal efficiencies $(\mathrm{R} \%)$ were calculated using Equation (1).

$$
\mathrm{R} \%=\frac{\mathrm{C}_{\mathrm{o}}-\mathrm{C}_{\mathrm{e}}}{\mathrm{C}_{\mathrm{o}}} \times 100
$$

where $\mathrm{C}_{0}$ and $\mathrm{C}_{\mathrm{e}}$ are the initial and equilibrium $\mathrm{Ni}(\mathrm{II})$ ion concentrations, respectively.

\subsection{Characterization of Biosorbent}

The Brunauer-Emmett-Teller (BET) surface area, pore size and pore volume after and before the adsorption process were investigated using Quanta Chrome NOVA 4200E Surface Area Analyzer. The morphology of the DSP was investigated using a scanning electron microscope technique (SEM) JEOL 6360 (Japan). Accelerating voltage of $20 \mathrm{kV}$ was used. The functional groups of DSP before and after the adsorption process were investigated by ATR-FTIR (Cary 630 FTIR from Agilent) in the range of $4000-400 \mathrm{~cm}^{-1}$ at a spectral resolution of $8 \mathrm{~cm}^{-1}$. DSP samples were analyzed without any pretreatment.

\section{Results and Discussion}

\subsection{Characterization of the DSP}

Table 1 displays the results of the analysis of DSP by surface area analyzer. Results prove that DSP poses a mesoporous arrangement. Mesopores are detected over the entire sample surface forming a highly uniform and interpenetrating permeable media. Moreover, results also confirm that DSP has a large surface area compared to some other adsorbents used to adsorb $\mathrm{Ni}(\mathrm{II})$ ions [13].

Table 1. Properties of the DSP surface.

\begin{tabular}{ccc}
\hline Surface Area $\left(\mathrm{m}^{2} / \mathrm{g}\right)$ & Total Pore Volume $\left(\mathrm{cm}^{3} / \mathrm{g}\right)$ & Average Pore Diameter $\left(\mathbf{A}^{\circ}\right)$ \\
\hline 124 & $46.9 \times 10^{-2}$ & 98 \\
\hline
\end{tabular}

\subsection{ATR-FTIR Spectrum}

Investigations of the ATR-FTIR spectra from DSP after and before the adsorption process (Figure 1) proves the presence of functional groups, which are among the major characteristic to DSP. The presence of developed aliphatic groups was identified by the absorption band ascribed to the stretching vibrations of carbon-hydrogen bonds in the range between $\left(2980-2840 \mathrm{~cm}^{-1}\right)$. OH functional groups were recognized by the broad band ascribed to stretching vibrations of oxygen-hydrogen bonds in the range from 3600 to $3100 \mathrm{~cm}^{-1}$, whereas, ether structures were identified by the band ascribed to stretching vibrations of carbon-oxygen in the range $\left(1100-1000 \mathrm{~cm}^{-1}\right)$. Moreover, CO groups were also detected by the band ascribed to stretching vibrations of $\mathrm{C}=\mathrm{O}$ bonds in the range from 1750 to $1500 \mathrm{~cm}^{-1}$. On the other hand, the bands of aromatic compounds bond groups overlay with those obtained by the bonds of other structures. Generally, the FTIR spectrum proves the multiplicity of the structure of DSP. The presence of these aforementioned functional groups on the DSP surface indicates its potential ability to act as a promising adsorbent [14].

\subsection{Scanning Electron Microscope Technique (SEM)}

The SEM technique investigations provided an insight into the diverse morphology of the DSP where some larger constituents show asymmetrical form, some other constituents have an extended rod-like construction whereas other smaller constituents display rectangular form. Overall, most of the constituents have a reedy and coarse structure with irregular ends. Particle size of the DSP ranges from $5-15 \mu \mathrm{m}$. It can be noted from Figure $2 \mathrm{a}$ the availability of numerous available cavities and holes 
enabling $\mathrm{Ni}$ (II) ions to be adsorbed, while Figure $2 \mathrm{~b}$ shows that these holes are occupied by $\mathrm{Ni}$ (II) ions indicating good adsorption capacity for DSP.

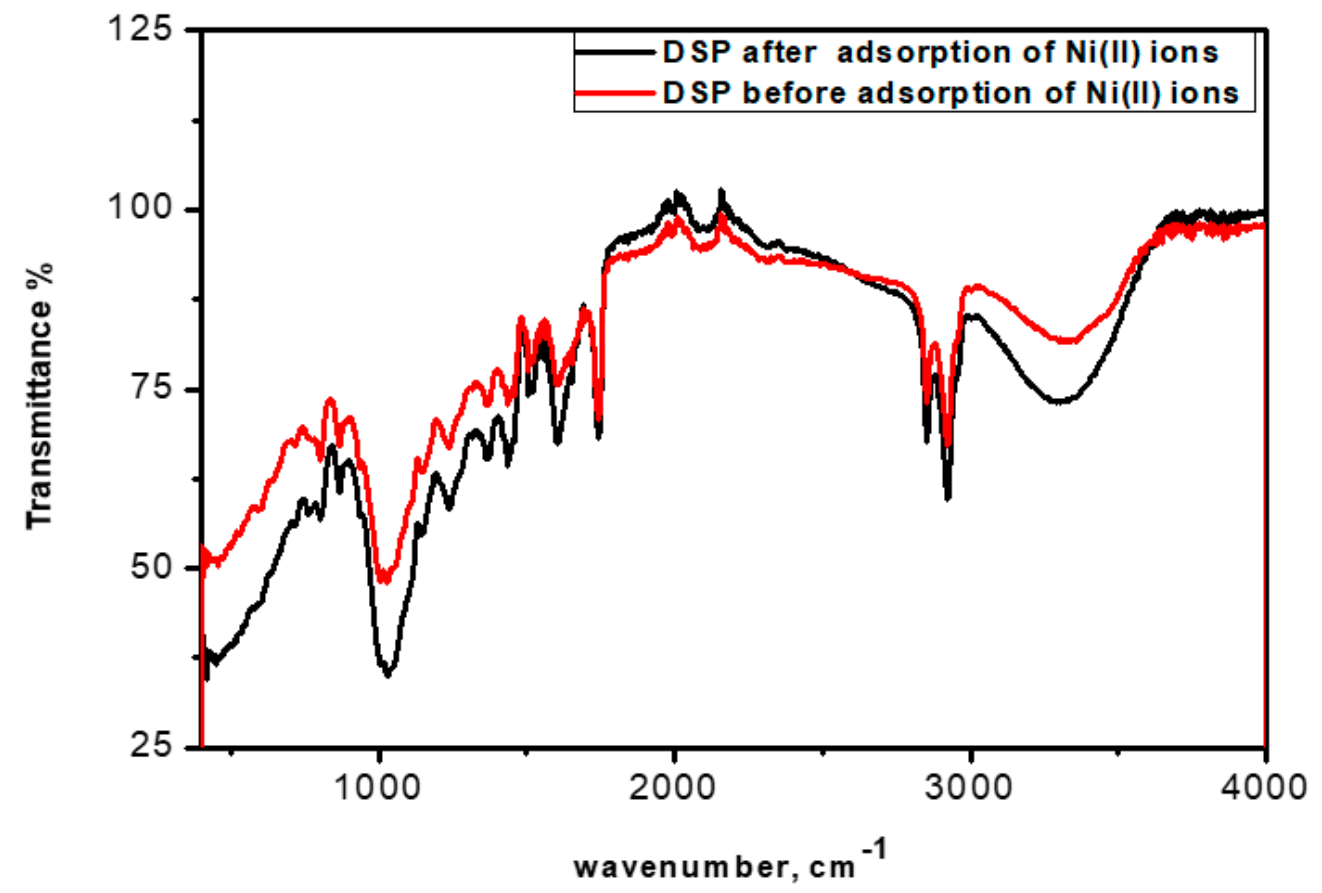

Figure 1. Attenuated total reflection-Fourier transform infrared spectrometer (ATR-FTIR) spectra for the date seeds powder (DSP) before and after Ni(II) ions adsorption process.

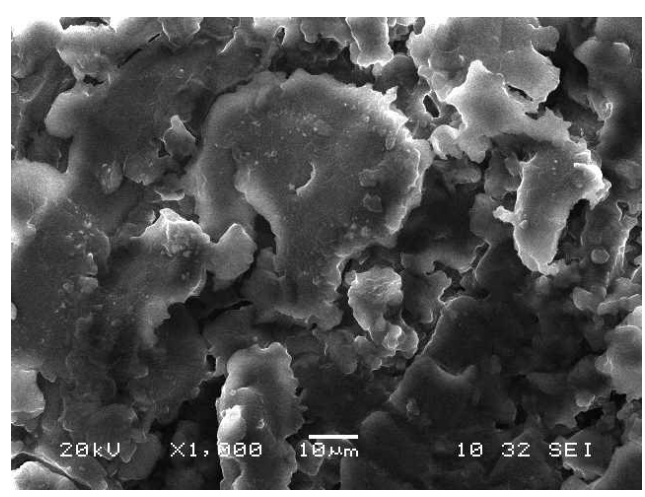

(a)

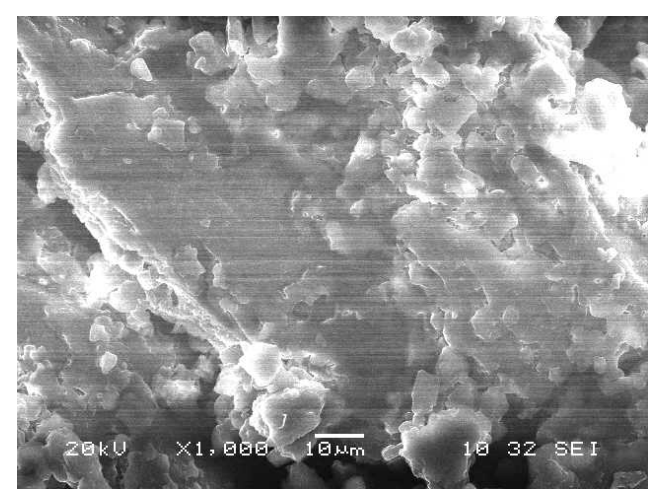

(b)

Figure 2. SEM technique images of the DSP surface (a) before and (b) after adsorption.

\subsection{Effect of $\mathrm{pH}$ Values}

A $\mathrm{pH}$ range of 1-11 was assessed to define the optimum value for the removal of $\mathrm{Ni}(\mathrm{II})$ ions by adsorption. Results are presented in Figure 3. It has been noted that the adsorption efficiency increases with increasing $\mathrm{pH}$ value up to 7 , after which no alteration was noted with further increase in the $\mathrm{pH}$ value. These results attributed to the competition between $\mathrm{Ni}(\mathrm{II})$ ions and $\mathrm{H}^{+}$ions for adsorption spots on the DSP surface at low $\mathrm{pH}$ values [15]. As the $\mathrm{pH}$ value increases, less $\mathrm{H}^{+}$ions are present; hence, more adsorption sites are available for $\mathrm{Ni}(\mathrm{II})$ ions. The optimal $\mathrm{pH}$ value was defined as 7; thus, been used throughout this work. 


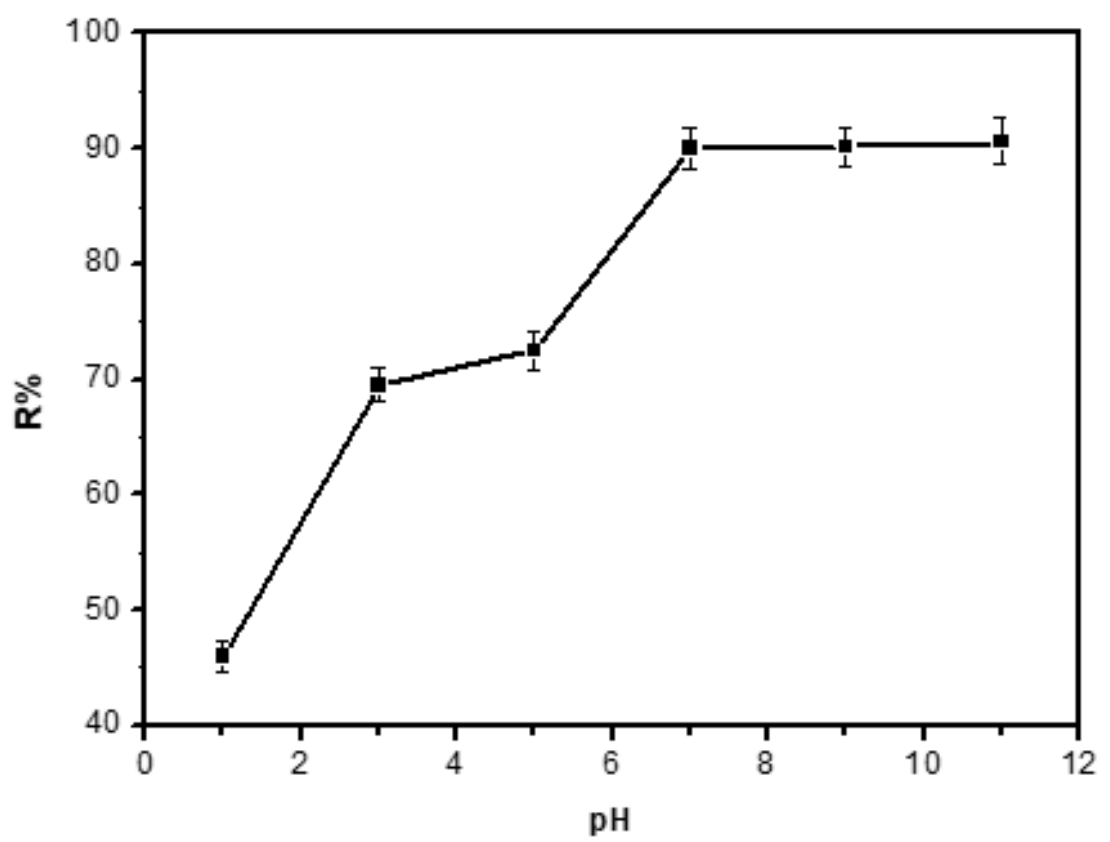

Figure 3. Effect of changing $\mathrm{pH}$ values on the efficiency of removal of $\mathrm{Ni}(\mathrm{II})$ ions.

\subsection{Effect of Adsorbent Particle Size}

Different particle sizes ranging from 100, 150, 250, 400, and $600 \mu \mathrm{m}$ have been examined and the obtained results (Figure 4) showed that as the particle size decreases, the removal amount increases from $82 \%$ to $90 \%$. This is due to the availability of more surface area obtainable for the removal of $\mathrm{Ni}$ (II) ions as the particle size decreases. However, no difference in adsorption was observed with particle sizes of 100 and $150 \mu \mathrm{m}$. Particle size of $100 \mu \mathrm{m}$ was used throughout the study.

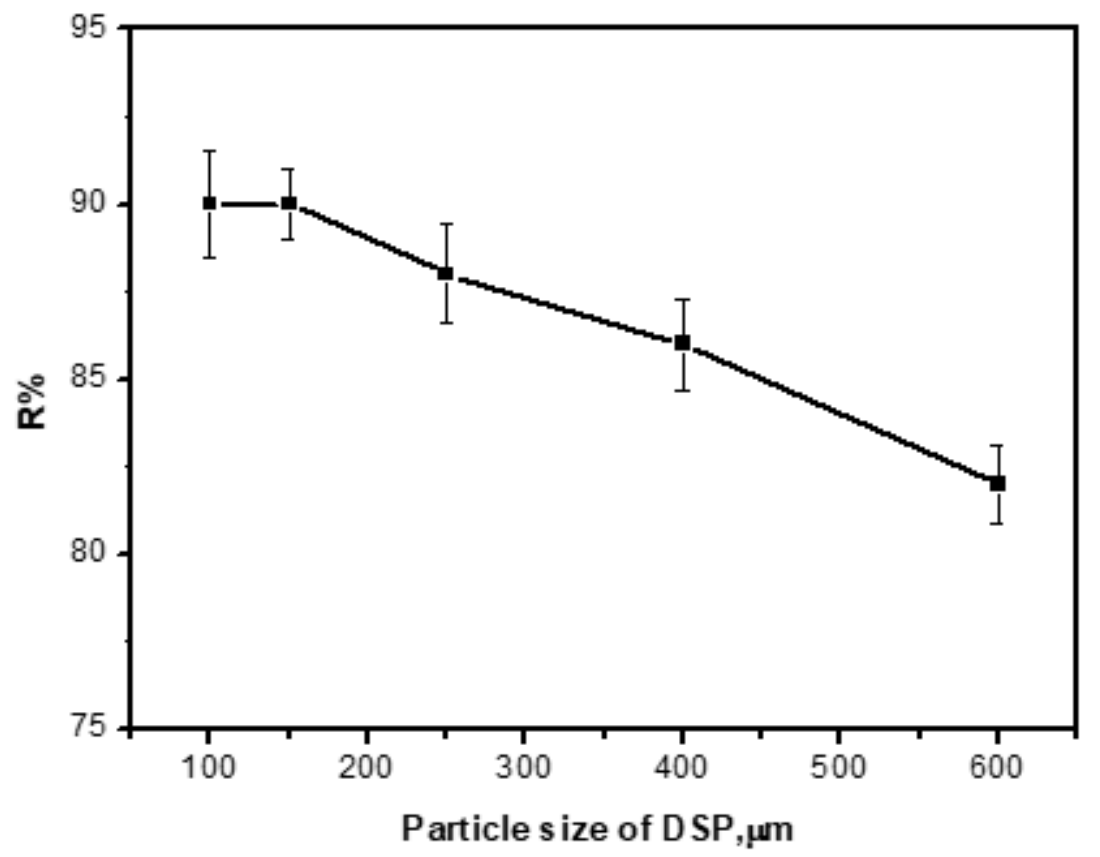

Figure 4. Effect of particle size of the DSP on the efficiency of removal of $\mathrm{Ni}(\mathrm{II})$ ions. 


\subsection{Effect of Adsorbent Mass}

The dependence of the adsorption efficiency on DSP mass was studied to determine the optimal mass. Results displayed in Figure 5 show that the removal efficiency of $\mathrm{Ni}$ (II) ions increased as the DSP mass increases from $0.05 \mathrm{~g}$ to $0.30 \mathrm{~g}$. Increasing the DSP mass to more than $0.30 \mathrm{~g}$ has no significant effect on adsorption effectiveness. This is due to the fact that the surface area of the adsorbent increases with its mass. The optimal DSP mass $(0.30 \mathrm{~g})$ was throughout this study.

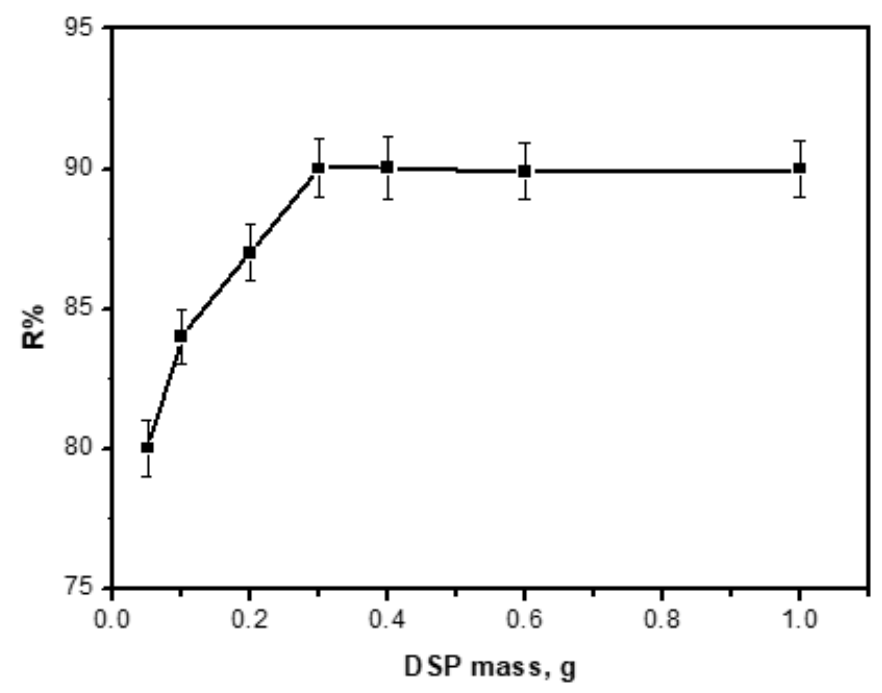

Figure 5. Effect of the DSP mass on the removal efficiency of $\mathrm{Ni}(\mathrm{II})$ ions.

\subsection{Effect of Contact Time}

In typical contaminant removal experiments, the contact time is considered a significant feature because it directly influences the adsorbent lifetime and the adsorption efficiency. Figure 6 shows the results obtained at different time intervals while all the other conditions $(\mathrm{pH}=7.00$, particle size $=100 \mu \mathrm{m}$, adsorbent mass $=0.30 \mathrm{~g}$ and temperature $=25.0^{\circ} \mathrm{C}$, revolutions per minute $(\mathrm{rpm})=150$ ) were kept constant. It was found that the DSP reached the maximum adsorption of $90 \%$ for $\mathrm{Ni}(\mathrm{II})$ after $30 \mathrm{~min}$.

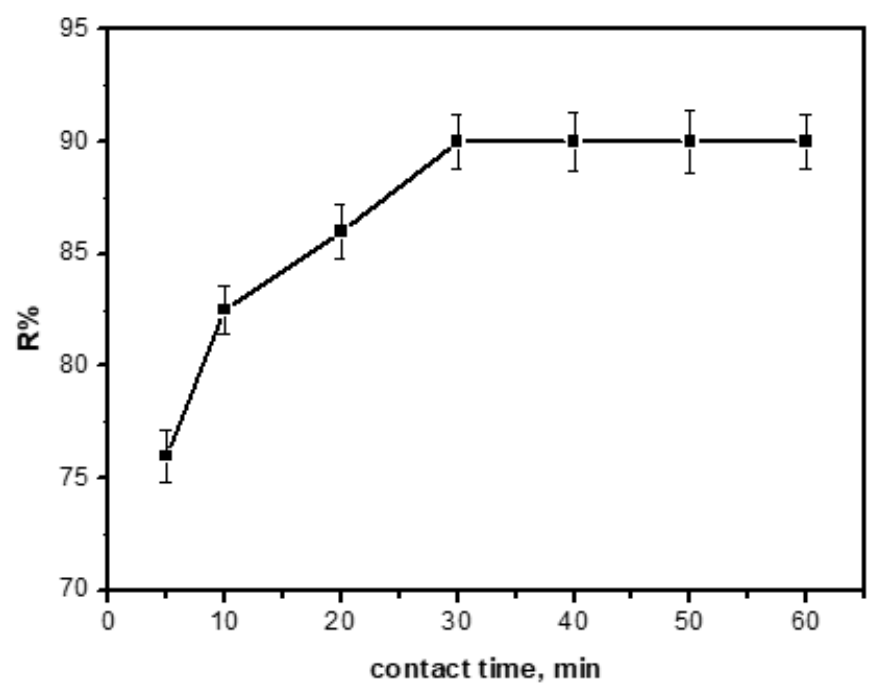

Figure 6. Effect of contact time on the efficiency of removal of $\mathrm{Ni}(\mathrm{II})$ ions. 


\subsection{Adsorption Kinetics}

Kinetics of the adsorption process is the key feature for designing efficient adsorption experiments and this requires the use of proper kinetic model. Several kinetic parameters values are shown in Table 2. Adsorption kinetics control the rate, $g$ the efficacy of DSP [16]. Several kinetic models were examined such as intraparticle diffusion, pseudo-second-order model, and pseudo-first-order.

Table 2. Kinetic parameters for the removal of Ni(II) ion by DSP.

\begin{tabular}{ccc}
\hline Kinetic Models & \multicolumn{2}{c}{ Parameters } \\
\hline & $\mathrm{q}_{\mathrm{e}}(\mathrm{mg} / \mathrm{g})$ & 12.2 \\
Pseudo-first-order model & $\mathrm{k}_{1}\left(\mathrm{~min}^{-1}\right)$ & $4.0 \times 10^{-4}$ \\
& $\mathrm{R}^{2}$ & 0.6988 \\
& $\mathrm{q}_{\mathrm{e}}(\mathrm{mg} / \mathrm{g})$ & 3.1 \\
Pseudo-second-order model & $\mathrm{k}_{2}(\mathrm{~g} / \mathrm{mg} \mathrm{min})$ & 0.3 \\
& $\mathrm{R}^{2}$ & 0.9937 \\
Intraparticle diffusion model & $\mathrm{k}_{\mathrm{id}}\left(\mathrm{mg} / \mathrm{g} \cdot \min ^{(1 / 2)}\right)$ & 0.056 \\
& $\mathrm{I}$ & 2.6 \\
& $\mathrm{R}^{2}$ & 0.7978 \\
\hline
\end{tabular}

\subsubsection{Pseudo-First-Order Model}

This model is denoted by Equation (2) [17].

$$
\ln \left(\mathrm{q}_{\mathrm{e}}-\mathrm{q}_{\mathrm{t}}\right)=\ln \mathrm{q}_{\mathrm{e}}-\mathrm{k}_{1} \mathrm{t}
$$

The pseudo-second order kinetic model is denoted by Equation (3).

$$
\frac{\mathrm{t}}{\mathrm{q}_{\mathrm{t}}}=\frac{1}{\mathrm{k}_{2} \mathrm{q}_{\mathrm{e}}^{2}}+\frac{\mathrm{t}}{\mathrm{q}_{\mathrm{e}}}
$$

where $\mathrm{q}_{\mathrm{e}}$ and $\mathrm{q}_{\mathrm{t}}$ are the equilibrium and adsorption capacities at time $(\mathrm{t})$ and equilibrium, and $\mathrm{k}_{1}$, $\mathrm{k}_{2}$ are rate constants for pseudo-first-order and pseudo-second-order, respectively. Moreover, 0.6977 and 0.9937 are values of correlation coefficients $\left(\mathrm{R}^{2}\right)$ for pseudo-first-order and pseudo-second-order models (Table 2), respectively. Figure 7 proves that the system obeys the pseudo-second-order kinetics model. This is in good agreement with previous studies [12,13,15].

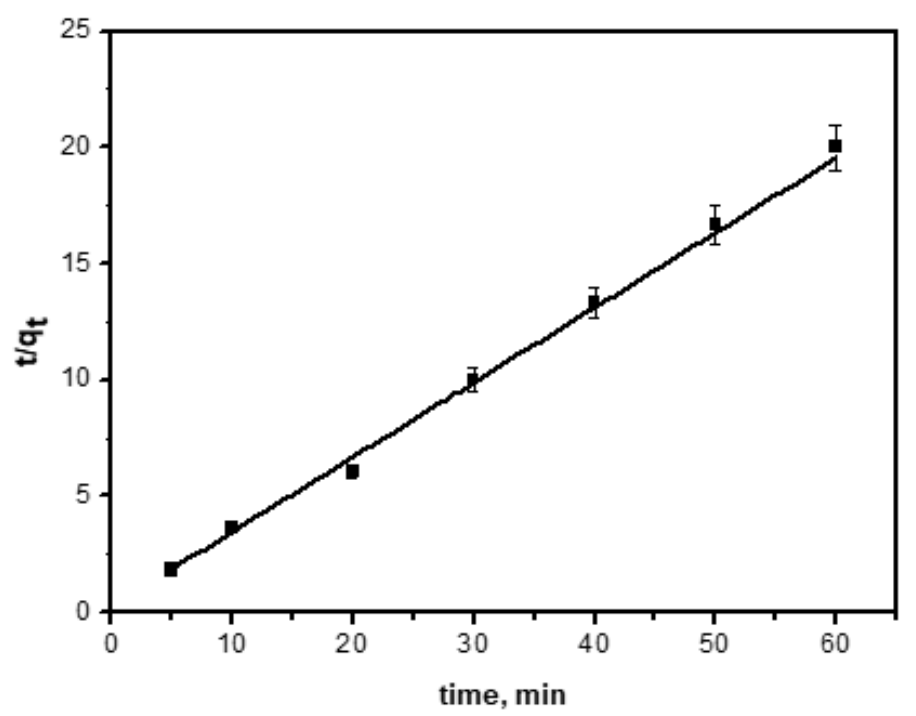

Figure 7. Pseudo-second-order kinetics. 


\subsubsection{Intra-Particle Diffusion Kinetic Model}

Intra-particle diffusion kinetic model is displayed by Equation (4)

$$
\mathrm{q}_{\mathrm{t}}=\mathrm{k}_{\mathrm{id}} \mathrm{t}^{1 / 2}+\mathrm{I}
$$

$\mathrm{k}_{\mathrm{id}}$ is the intra-particle diffusion rate constant $\left(\mathrm{mg} / \mathrm{g} \cdot \min ^{(1 / 2)}\right)$ and $\mathrm{I}$ is a constant that associated to the boundary layer thickness $(\mathrm{mg} / \mathrm{g})$. The value of $\left(\mathrm{k}_{\mathrm{id}}\right)$ was determined from the slope of Equation (4) and presented in Table 2 . The relationship between $\mathrm{q}_{\mathrm{t}}$ and $\mathrm{t}_{1 / 2}$ was non-linear, demonstrating that several processes are governing the adsorption process. The initial curved portion of the plot is due to the impact of boundary layer diffusion. The curved portion denotes that the intra-particle diffusion is controlled by the rate of constant $\mathrm{k}_{\mathrm{id}}$.

\subsection{Adsorption Isotherm}

Adsorption models are frequently exploited to explain the adsorbate/adsorbent interactions to determine the adsorption capacity of the adsorbent. To evaluate the adsorption isotherms for the DSP, Freundlich, Langmuir, Temkin, and Dubinin-Radushkevich (D-R) adsorption models were examined.

\subsubsection{Langmuir Model}

Equation (5) presents the Langmuir linear equation

$$
\frac{\mathrm{C}_{\mathrm{e}}}{\mathrm{q}_{\mathrm{e}}}=\frac{\mathrm{C}_{\mathrm{e}}}{\mathrm{q}_{\mathrm{m}}}+\frac{1}{\mathrm{bq}_{\mathrm{m}}}
$$

where $\mathrm{q}_{\mathrm{e}}$ is the equilibrium quantity of $\mathrm{Ni}(\mathrm{II})$ ions adsorbed on the DSP surface at equilibrium (mg/g), $\mathrm{C}_{\mathrm{e}}$ is the equilibrium concentration of $\mathrm{Ni}(\mathrm{II})$ ions in solution $(\mathrm{mg} / \mathrm{L}), \mathrm{q}_{\mathrm{m}}$ is the maximum adsorption of $\mathrm{Ni}(\mathrm{II})$ ions $(\mathrm{mg} / \mathrm{g})$, and $\mathrm{b}(\mathrm{L} / \mathrm{mg})$ is the Langmuir constant. According to Equation (4), values of $\mathrm{C}_{\mathrm{e}} / \mathrm{q}_{\mathrm{e}}$ were plotted against $\mathrm{C}_{\mathrm{e}}$ and the results are displayed in Figure $8 \mathrm{a}$. Values of $\mathrm{q}_{\mathrm{m}}$ and $\mathrm{b}$ were obtained from the slope and intercept, respectively. The $b$ value refers to the adsorption binding energy [14], whereby a higher $b$ value means more binding affinity between adsorbent and adsorbate. The parameters $\left(\mathrm{q}_{\mathrm{m}}, \mathrm{b}\right.$ and $\left.\mathrm{R}^{2}\right)$ are displayed in Table 3 .

Table 3. Parameters obtained from various isotherm models.

\begin{tabular}{ccc}
\hline Adsorption Model & Isotherm Constants & Value \\
\hline \multirow{3}{*}{ Langmuir } & $\mathrm{q}_{\max }(\mathrm{mg} / \mathrm{g})$ & 40.8 \\
& $\mathrm{~K}_{\mathrm{L}}(\mathrm{L} / \mathrm{g})$ & 0.029 \\
$\mathrm{R}^{2}$ & 0.887 \\
\hline \multirow{2}{*}{ Freundlich } & $\mathrm{N}$ & 0.67 \\
& $\mathrm{~K}_{\mathrm{f}}((\mathrm{mg} / \mathrm{g}) /(\mathrm{mg} / \mathrm{L}) \mathrm{n})$ & 4.6 \\
$\mathrm{R}^{2}$ & 0.9981 \\
\hline \multirow{2}{*}{ Temkin } & $\mathrm{A}(\mathrm{L} / \mathrm{g})$ & 2.1 \\
& $\mathrm{~b}_{\mathrm{t}}(\mathrm{kJ} / \mathrm{mol})$ & 370.3 \\
$\mathrm{R}^{2}$ & 0.899 \\
\hline \multirow{2}{*}{$\mathrm{D}-\mathrm{R}$} & $\beta$ & $2.0 \times 10^{-7}$ \\
& $\mathrm{q}_{\mathrm{m}}(\mathrm{mg} / \mathrm{g})$ & 7.18 \\
$\mathrm{R}^{2}$ & 0.846 \\
\hline
\end{tabular}



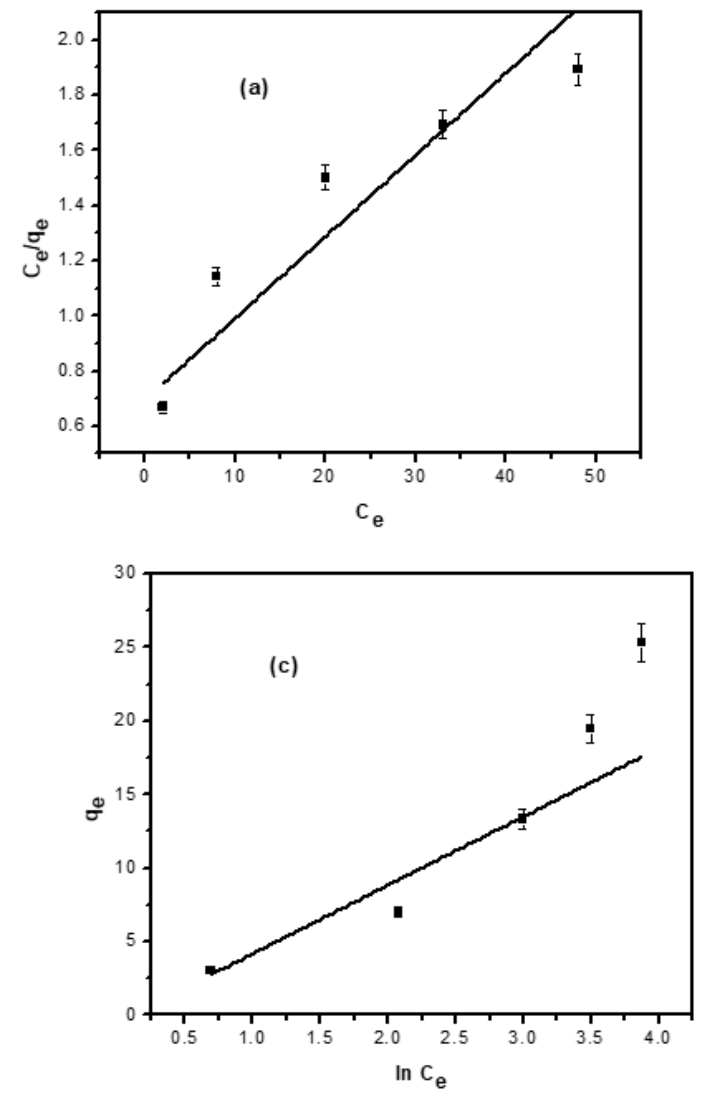
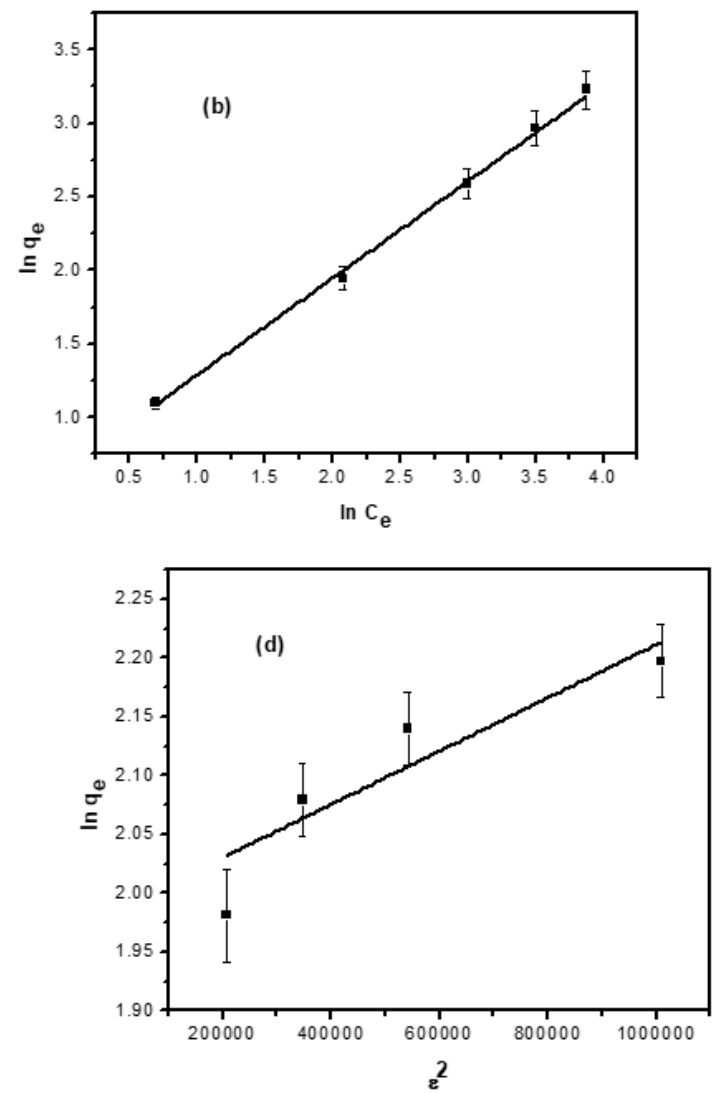

Figure 8. Isotherm models of adsorption of Ni(II) ions by the DSP (a), Langmuir, (b) Freundlich, (c) Temkin and (d) D-R.

\subsubsection{Freundlich Model}

This is an experimental association relating the adsorption of solutes from a liquid onto an adsorbent surface and adopts that various adsorption layers with a number of adsorption energies are involved. This model describes the affinity between the quantities of $\mathrm{Ni}$ (II) ions adsorbed per the dosage of the DSP, $\mathrm{q}_{\mathrm{e}}$, and the concentration of the $\mathrm{Ni}(\mathrm{II})$ ions at equilibrium, $\mathrm{C}_{\mathrm{e}}$. Linear Freundlich model is represented by Equation (6) [12].

$$
\ln \mathrm{q}_{\mathrm{e}}=\ln \mathrm{K}_{\mathrm{f}}+\frac{1}{\mathrm{n}} \ln \mathrm{C}_{\mathrm{e}}
$$

where $n$ and $K_{f}$ represent Freundlich constants describe the process intensity capacity. Values of $K_{f}$ and $n$ are obtained from the intercept and slope of Figure $8 b$, respectively. Value of $n$ is an indicator to the adsorption nature according to the following way: if $\mathrm{n}<1$, adsorption is classified as a physical process, if $\mathrm{n}=1$, adsorption is linear and if $\mathrm{n}>1$, adsorption is considered as a chemical process. The range of $n$ values and $K_{f}$ value are given in Table 3. Results indicate that adsorption of Ni(II) ion on the surface of the DSP is a physical process [13].

\subsubsection{Temkin Isotherm}

Temkin model proposes that the adsorption heat of all particles in the layer decrease sharply, rather than logarithmic with coverage [18]. The adsorption potential of DSP to Ni(II) ions can be verified by applying Temkin isotherm model. The linear formula of Temkin is shown in Equation (7):

$$
\mathrm{q}_{\mathrm{e}}=\frac{\mathrm{RT}}{\mathrm{b}_{\mathrm{t}}} \ln \mathrm{A}+\frac{\mathrm{RT}}{\mathrm{b}_{\mathrm{t}}} \ln \mathrm{C}_{\mathrm{e}}
$$


where $\mathrm{R}$ is the universal gas constant, $\mathrm{T}$ is the absolute temperature, $\mathrm{b}_{t}$ is Temkin constant associated with adsorption heat, and $\mathrm{A}$ is a constant related to adsorption capacity. A and $\mathrm{b}_{\mathrm{t}}$ values are found from the slope and intercept of Figure $8 \mathrm{c}$ and given along with $\mathrm{R}^{2}$ in Table 3.

\subsubsection{Dubinin-Radushkevich (D-R) Isotherm Model}

This model estimates the energy of adsorption. It is commonly used to understand the mechanism of adsorption [19]. This isotherm is not proposed only for constant adsorption potential or homogeneous adsorbent but also for both heterogonous surfaces. The linear equation of this model is presented in Equation (8):

$$
\ln \mathrm{q}_{\mathrm{e}}=\ln \mathrm{q}_{\mathrm{m}}-\beta \varepsilon^{2}
$$

$\varepsilon$ is given by Equation (9):

$$
\varepsilon=\mathrm{RT} \ln \left(1+\frac{1}{\mathrm{C}_{\mathrm{e}}}\right)
$$

$\beta$ is a constant associated with the adsorption free energy, $q_{m}$ is the theoretical saturation capacity based on D-R isotherm $(\mathrm{mg} / \mathrm{g})$. Values of $\beta, \mathrm{q}_{\mathrm{m}}$ and $\mathrm{R}^{2}$ are obtained from Figure $8 \mathrm{~d}$ and shown in Table 3. The free sorption energy $E_{s}$, is the change in free energy when one mole of adsorbate is stimulated to the solid surface and is calculated by Equation (10).

$$
\mathrm{E}_{\mathrm{s}}=\frac{1}{\sqrt{2 \beta}}
$$

The adsorption type can be deduced from the $\mathrm{E}_{\mathrm{s}}$ value. The adsorption process is considered chemical when $E_{\mathrm{s}}$ value is in the range 8.0 to $16.0 \mathrm{~kJ} / \mathrm{mol}$ and physical when $E_{\mathrm{s}}$ is less than $8.0 \mathrm{~kJ} / \mathrm{mol}$. In this work, the $\mathrm{E}_{\mathrm{s}}$ value was determined as $2.24 \mathrm{~kJ} / \mathrm{mol}$ concluding that the adsorption taking action is of physical nature.

\subsection{Effect of Temperature}

Figure 9 displays the influence of temperature on the adsorption of $\mathrm{Ni}(\mathrm{II})$ ions onto the DSP surface. The adsorption efficiency decreases as the temperature increases. This is justified due to the damage of some adsorption sites at elevated temperatures.

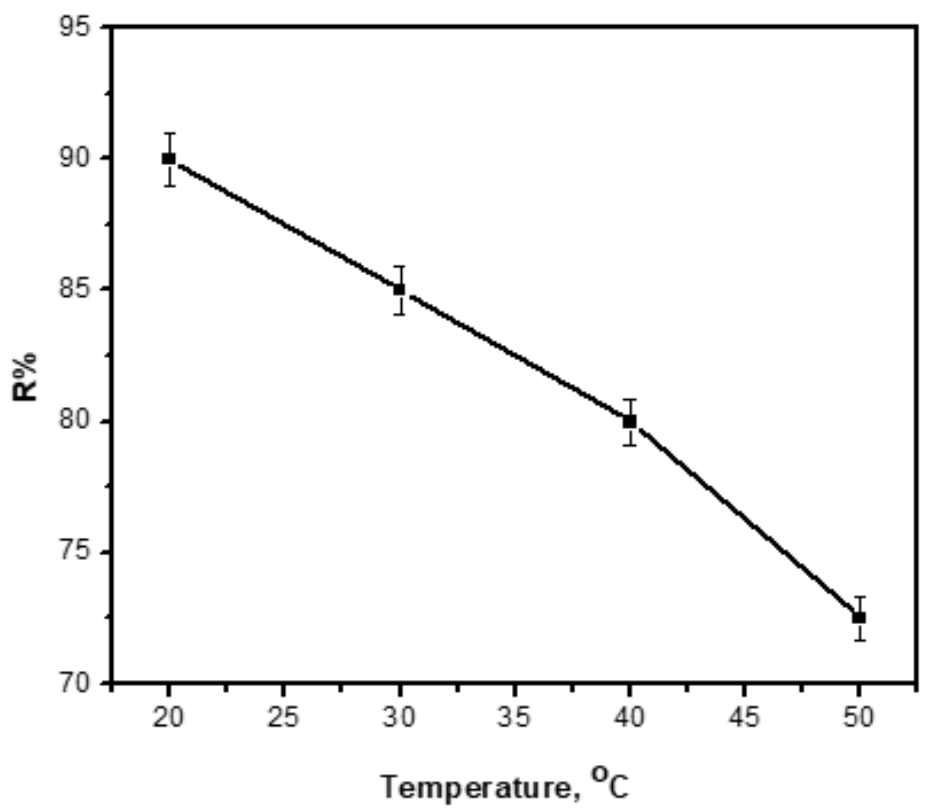

Figure 9. Effect of temperature on the removal efficiency of Ni(II) ions by the DSP. 


\subsection{Adsorption Thermodynamics}

Thermodynamical parameters are vital in any adsorption investigations as the temperature is strongly connected to the kinetic energy of adsorbate. In this study, adsorption tests were performed at different temperatures, viz. 298, 308, 318 and $328 \mathrm{~K}$ for the sorption of initial $\mathrm{Ni}(\mathrm{II})$ ion concentration $(50 \mathrm{mg} / \mathrm{L})$ on DSP at their particular optimum $\mathrm{pH}$ values, DSP mass and contact time. Entropy $\left(\Delta \mathrm{S}^{\circ}\right)$, enthalpy $\left(\Delta \mathrm{H}^{\circ}\right)$, and Free energy $\left(\Delta \mathrm{G}^{\circ}\right)$ change are governed by Equations (11) and (12).

$$
\begin{gathered}
\Delta \mathrm{G}^{\mathrm{o}}=\mathrm{RT} \ln \mathrm{K}_{\mathrm{D}} \\
\ln \mathrm{K}_{\mathrm{D}}=\frac{-\Delta \mathrm{H}^{\mathrm{o}}}{\mathrm{RT}}+\frac{\Delta \mathrm{S}^{\mathrm{o}}}{\mathrm{R}}
\end{gathered}
$$

where $K_{D}$ value were calculated by Equation (13)

$$
\mathrm{K}_{\mathrm{D}}=\frac{\mathrm{q}_{\mathrm{e}}}{\mathrm{C}_{\mathrm{e}}}
$$

The thermodynamical parameters are listed in Table 4 . Negative signs of $\Delta \mathrm{G}^{\circ}$ indicate that the process is spontaneous. It is clear that the negative values of $\Delta \mathrm{G}^{\circ}$ decrease as the temperature increases. This is attributed to the fact that additional positions on the surface of the DSP are destroyed at elevated temperatures. Values of $\Delta \mathrm{G}^{\circ}$ for $\mathrm{Ni}$ (II) ions adsorption onto the DSP were found in the range of -3.5 to $-5.7 \mathrm{~kJ} / \mathrm{mol}$. It is well established that physical adsorption free energy change $\left(\Delta \mathrm{G}^{\circ}\right)$ is ranging between -20 and $0 \mathrm{~kJ} / \mathrm{mol}$ and chemical adsorption between -400 to $-80 \mathrm{~kJ} / \mathrm{mol}$ [13]. Thus, adsorption process is mainly a physical sorption process. This finding is in good agreement with the parameters obtained from Freundlich, Dubinin-Radushkevich (D-R) and Temkin models. $\Delta \mathrm{S}^{\circ}$ and $\Delta \mathrm{H}^{\circ}$ were calculated from the intercept and slope of Figure 10 and presented in Table 3 . The negative value of $\Delta \mathrm{H}^{\circ}(-27.0 \mathrm{~kJ} / \mathrm{mol})$ proves that the adsorption is an exothermic process. The positive value of $\Delta S^{\circ}$ $(71.0 \mathrm{~J} / \mathrm{mol})$ designates the affinity of the DSP towards the $\mathrm{Ni}(\mathrm{II})$ ions.

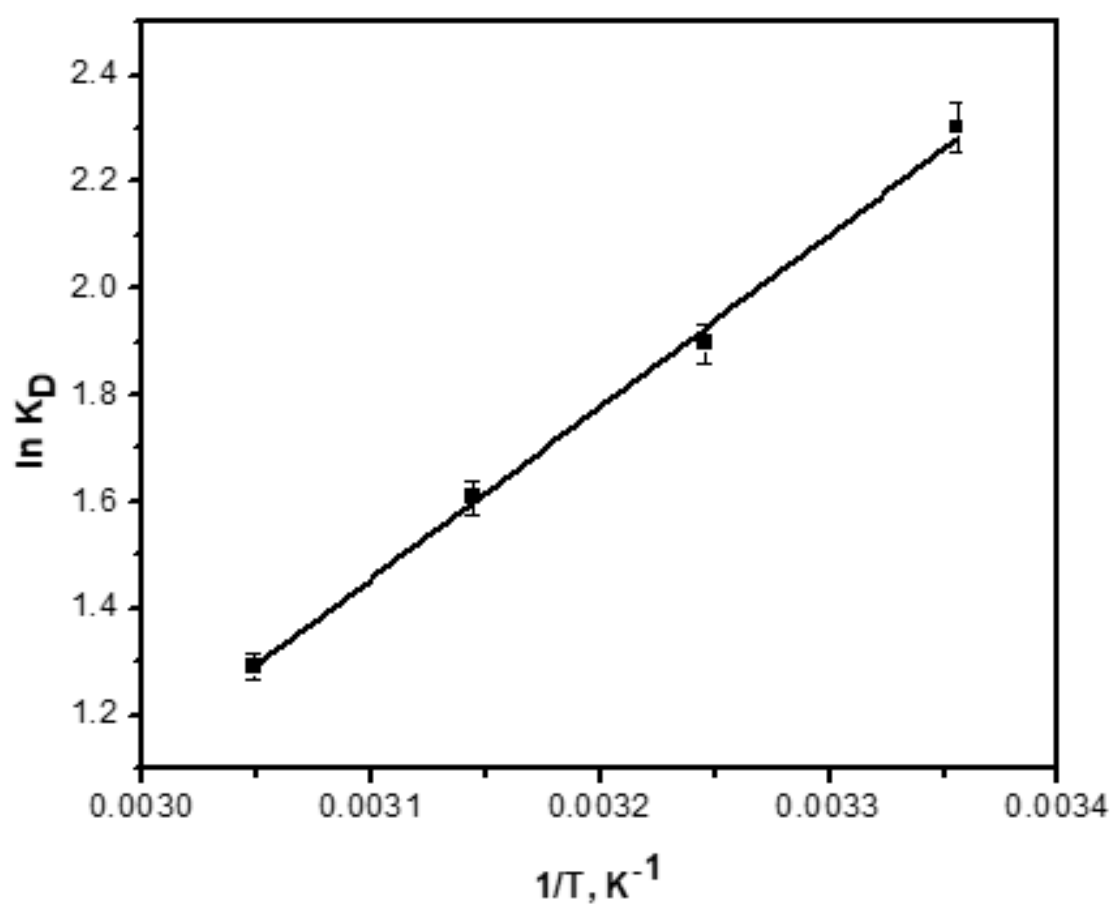

Figure 10. Relationship between $\ln \mathrm{K}_{\mathrm{D}}$ and $1 / \mathrm{T}$. 
Values of sticking probability $\left(\mathrm{S}^{*}\right)$ and activation energy (Ea) were calculated by applying the modified Arrhenius equation that shown in Equations (14) and (15) [19]:

$$
\begin{aligned}
S^{*} & =(1-\theta) e^{\frac{-E_{a}}{R T}} \\
\theta & =\left(1-\frac{C_{e}}{C_{i}}\right)
\end{aligned}
$$

where $\theta$ is the surface coverage, $C_{i}$ represents the original concentration of $\mathrm{Ni}(\mathrm{II})$ ions, $\mathrm{E}_{\mathrm{a}}$ is the activation energy of the system and $\mathrm{S}^{*}$ is the sticking probability.

The sticking probability, $\mathrm{S}^{*}$, is a function of the adsorbent/adsorbate adsorption process but should fulfil the circumstance $0<\mathrm{S}^{*}<1$ and depends on the temperature of the process. $\mathrm{E}_{\mathrm{a}}$ and $\mathrm{S}^{*}$ values were obtained from the slope and intercept of Figure 10, and are recorded in Table 4. The Ea value is very low $(-2.01 \mathrm{~kJ} / \mathrm{mol})$ demonstrating the facile adsorption process and the negative charge of $E_{a}$ value indicates an exothermic process. This is in good agreement with the negative value of $\Delta \mathrm{H}^{\circ}$ [15]. Since the value of $S^{*}<<<1$, therefore, the probability of Ni(II) ion to stick on the DSP is very high and thus the adsorption process is favorable [18].

\begin{tabular}{|c|c|c|c|c|c|c|}
\hline $\mathrm{T}, \mathrm{K}$ & $K_{D}$ & $\begin{array}{c}\Delta \mathrm{G}^{\circ} \\
(\mathrm{kJ} / \mathrm{mol})\end{array}$ & $\begin{array}{c}\Delta S^{\circ} \\
(\mathrm{J} / \mathrm{mol} \mathrm{K})\end{array}$ & $\begin{array}{c}\Delta H^{\circ} \\
(\mathrm{kJ} / \mathrm{mol})\end{array}$ & $\begin{array}{c}E_{a} \\
(k J / m o l)\end{array}$ & $\begin{array}{c}S^{*} \\
(\mathrm{~J} \mathrm{~K} / \mathrm{mol})\end{array}$ \\
\hline 298 & 10.0 & -5.7 & & & & \\
\hline 308 & 6.7 & -4.9 & 71.7 & -27.0 & -2.01 & 0.002 \\
\hline 318 & 5.0 & -4.2 & & & & \\
\hline 328 & 3.6 & -3.5 & & & & \\
\hline
\end{tabular}

Table 4. Values of thermodynamic parameters.

\subsection{Comparisons with Other Adsorbents}

Table 5 presents the results of this study compared with other biosorbents. Under the same experimental conditions in terms of optimum $\mathrm{pH}$, temperature, DSP proved high adsorption efficiency in contrast to the chosen biosorbents. It is interesting to note that the DSP was used without any further chemical or thermal modifications. This reduces its cost and hazard to the minimum.

\begin{tabular}{|c|c|c|c|c|c|}
\hline Biosorbent & $q_{m}(m g / g)$ & Isotherm Model & Kinetic Model & Optimal pH & Reference \\
\hline Date seeds powder & 41.0 & Freundlich & 2nd order & 7.00 & This study \\
\hline Aloe barbadensis Miller leaves & 10.0 & Freundlich & 2nd order & 3.00 & [20] \\
\hline peel of Artocarpus nobilis fruit & 12.1 & Langmuir & $* *$ & 4.00 & [21] \\
\hline Modified Aloe barbadensis leaves & 29.0 & Langmuir & 2nd order & 7.00 & [22] \\
\hline brown algae Sargassum sp. & 1.3 & Langmuir & 2nd order & 6.50 & [23] \\
\hline Calotropis procera roots & 0.6 & Langmuir & $* *$ & 3.00 & [24] \\
\hline Peat & 61.3 & Langmuir & 2nd order & 9.00 & [14] \\
\hline Barely straw & 35.8 & Langmuir & $* *$ & 4.85 & [25] \\
\hline Orange peel & 162.6 & Langmuir & 2nd order & 5.50 & [26] \\
\hline Tea factory waste & 18.4 & Langmuir & $* *$ & 4.00 & [27] \\
\hline
\end{tabular}

Table 5. Comparison of the DSP with other biosorbents used for the removal of $\mathrm{Ni}(\mathrm{II})$ ions.

\section{Conclusions}

In this study, the powder obtained from date seeds has been tested as a competent (removal effectiveness $>90 \%$ ), inexpensive, eco-friendly and natural material for adsorption of $\mathrm{Ni}(\mathrm{II})$ ions from artificial wastewater. The date seeds powder retained significant amounts of $\mathrm{Ni}$ (II) readily. The maximum adsorption capacity for DSP was found to be $41 \mathrm{mg} / \mathrm{g}$. The optimal conditions for efficient removal of $50 \mathrm{ppm}$ of $\mathrm{Ni}(\mathrm{II})$ ion were found to be $0.30 \mathrm{~g}$ of DSP after $30 \mathrm{~min}$ of shaking time 
at $\mathrm{pH}$ 7.00. This adsorbent has positive characteristics making it appropriate to purify wastewater. Such characteristics include (i) cost-effective material: date seeds powder is an expensive material. The only cost of this material would be for the collection, transportation and grinding. It does not need any further chemical or thermal modification (ii) availability: date seeds are abundantly existing in Saudi Arabia (iii) efficiency: date seeds powder can remove more than $90 \%$ of $\mathrm{Ni}$ (II) ions, which present in artificial wastewater.

Author Contributions: Conceptualization I.H.A. and A.E.; methodology, A.E.; validation, E.I.B.; formal analysis, E.I.B.; investigation A.E.; resources, A.B.E.; writing—original draft preparation, I.H.A. and A.E.; writing-review and editing, E.I.B.; supervision, B.K.; project administration, I.H.A.; funding acquisition, A.B.E. All authors have read and agreed to the published version of the manuscript.

Funding: This research was funded by DEANSHIP OF SCIENTIFIC RESEARCH, KING KHALID UNIVERSITY, grant number R.G.P.1/139/40.

Conflicts of Interest: The authors declare no conflict of interest.

\section{References}

1. Kulkarni, R.M.; Shetty, K.V.; Srinikethan, G. Cadmium (II) and nickel (II) biosorption by Bacillus laterosporus (MTCC 1628). J. Taiwan Inst. Chem. Eng. 2014, 45, 1628-1635. [CrossRef]

2. Putra, W.P.; Kamari, A.; Yusoff, S.N.M.; Ishak, C.F.; Mohamed, A.; Hashim, N.; Isa, I.M. Biosorption of $\mathrm{Cu}$ (II), $\mathrm{Pb}$ (II) and $\mathrm{Zn}$ (II) ions from aqueous solutions using selected waste materials: Adsorption and characterisation studies. J. Encapsul. Adsorpt. Sci. 2014, 4, 720-726.

3. Karatas, M. Removal of $\mathrm{Pb}$ (II) from water by natural zeolitic tuff: Kinetics and thermodynamics. J. Hazard. Mater. 2012, 199, 383-393. [CrossRef] [PubMed]

4. Ahmad, T.; Danish, M.; Rafatullah, M.; Ghazali, A.; Sulaiman, O.; Hashim, R.; Ibrahim, M.N.M. The use of date palm as a potential adsorbent for wastewater treatment: A review. Environ. Sci. Pollut. Res. 2012, 19, 1464-1468. [CrossRef]

5. Lee, C.G.; Lee, S.; Park, J.A.; Park, C.; Lee, S.J.; Kim, S.B.; An, B.; Yun, S.T.; Lee, S.H.; Choi, J.W. Removal of copper, nickel and chromium mixtures from metal plating wastewater by adsorption with modified carbon foam. Chemosphere 2017, 166, 203-211. [CrossRef]

6. Prithviraj, D.; Deboleena, K.; Neelu, N.; Noor, N.; Aminur, R.; Balasaheb, K.; Abul, M. Biosorption of nickel by Lysinibacillus sp. BA2 native to bauxite mine. Ecotoxicol. Environ. Saf. 2014, 107, 260-268. [CrossRef]

7. Salem, N.M.; Awwad, A.M. Biosorption of $\mathrm{Ni}(\mathrm{II})$ from electroplating wastewater by modified (Eriobotrya japonica) loquat bark. J. Saudi Chem. Soc. 2014, 18, 379-386. [CrossRef]

8. Onundi, Y.B.; Mamun, A.A.; Al Khatib, M.F.; Ahmed, M. Adsorption of copper, nickel and lead ions from synthetic semiconductor industrial wastewater by palm shell activated carbon. Int. J. Environ. Sci. Technol. 2010, 7, 751-758. [CrossRef]

9. Alomá, I.; Martín-Lara, M.A.; Rodríguez, I.L.; Blázquez, G.; Calero, M. Removal of nickel (II) ions from aqueous solutions by biosorption on sugarcane bagasse. J. Taiwan Inst. Chem. Eng. 2012, 43, 275-281. [CrossRef]

10. El Marouani, M.; Azoulay, K.; Bencheikh, I.; Elfakir, L.; Rghioui, L.; El Hajji, A.; Sebbahi, S.; El Hajjaji, S.; Kifani-Sahban, F. Application of raw and roasted date seeds for dyes removal from aqueous solution. J. Mater. Environ. Sci. 2018, 9, 2387-2396.

11. Chang, Y.S.; Au, P.I; Mubarak, N.M.; Khalid, M.; Jagadish, P.; Walvekar, R.; Abdullah, E.C. Adsorption of $\mathrm{Cu}(\mathrm{II})$ and $\mathrm{Ni}(\mathrm{II})$ ions from wastewater onto bentonite and bentonite/GO composite. Environ. Sci. Pollut. Res. 2020, 27, 33270-33296. [CrossRef] [PubMed]

12. Mehrmad, N.; Moravegi, M.; Parvareh, A. Adsorption of $\mathrm{Pb}(\mathrm{II}), \mathrm{Cu}(\mathrm{II})$ and $\mathrm{Ni}(\mathrm{II})$ ions from aqueous solutions by functionalised henna powder (Lawsonia Inermis); isotherm, kinetic and thermodynamic studies. Int. J. Environ. Anal. Chem. 2020. [CrossRef]

13. Khan, M.I.; Almesfer, M.K.; Danish, M.; Ali, I.H.; Shoukry, H.; Patel, R.; Gardy, J.; Nizami, A.S.; Rehan, M. Potential of Saudi natural clay as an effective adsorbent in heavy metals removal from wastewater. Desalin. Water Treat. 2019, 158, 140-151. [CrossRef] 
14. Bartczak, P.; Norman, M.; Klapiszewski, L.; Karwan'ska, N.; Kawalec, M.; Baczyn'ska, M.; Wysokowski, M.; Zdarta, J.; Ciesielczyk, F.; Jesionowski, T. Removal of nickel(II) and lead(II) ions from aqueous solution using peat as a low-cost adsorbent: A kinetic and equilibrium study. Arab. J. Chem. 2018, 11, 1209-1222. [CrossRef]

15. Ali, I.H.; Al Mesfer, M.K.; Khan, M.I.; Danish, M.; Alghamdi, M.M. Exploring Adsorption Process of Lead (II) and Chromium (VI) Ions from Aqueous Solutions on Acid Activated Carbon Prepared from Juniperus procera Leaves. Processes 2019, 7, 217. [CrossRef]

16. Chang, C.F.; Chang, C.Y.; Chen, K.H.; Tsai, W.T.; Shie, J.L.; Chen, Y.H. Adsorption of naphthalene on zeolite from aqueous solution. J. Colloid. Interface Sci. 2004, 277, 29-34. [CrossRef]

17. Ali, I.H.; Sulfab, Y. Kinetics and mechanism of oxidation of cisdiaquabis(glycinato)chromium(III) by periodate ion in aqueous solutions. Transit. Met. Chem. 2013, 38, 79-84. [CrossRef]

18. Tempkin, M.I.; Pyzhev, V. Kinetic of Ammonia Synthesis on Promoted Iron Catalyst. Acta Phys. Chim. USSR 1940, 12, 327-356.

19. Günay, A.; Arslankaya, E.; Tosun, I. Lead removal from aqueous solution by natural and pretreated clinoptilolite: Adsorption equilibrium and kinetics. J. Hazard. Mater. 2007, 146, 362-371. [CrossRef]

20. Gupta, S.; Kumar, A. Removal of nickel (II) from aqueous solution by biosorption on A. barbadensis Miller waste leaves powder. Appl. Water Sci. 2019, 9, 96-107. [CrossRef]

21. Priyantha, N.; Kotabewatta, P.A. Biosorption of heavy metal ions on peel of Artocarpus nobilis fruit: $1-\mathrm{Ni}(\mathrm{II})$ sorption under static and dynamic conditions. Appl. Water Sci. 2019, 9, 37-47. [CrossRef]

22. Gupta, S.; Sharma, S.K.; Kumar, A. Biosorption of Ni(II) ions from aqueous solution using modified Aloe barbadensis Miller leaf powder. Water Sci. Eng. 2019, 12, 27-36. [CrossRef]

23. Barquilha, C.E.R.; Cossich, E.S.; Tavares, C.R.; Silva, E.A. Biosorption of nickel(II) and copper(II) ions by Sargassum sp. in nature and alginate extraction products. Bioresour. Technol. Rep. 2019, 5, 43-50. [CrossRef]

24. Pandey, P.K.; Choubey, S.; Verma, Y.; Pandey, M.; Kamal, S.S.; Chandrashekhar, K. Biosorptive removal of $\mathrm{Ni}(\mathrm{Ii})$ from wastewater and industrial effluent. Int. J. Environ. Res. Public Health 2007, 4, 332-339. [CrossRef] [PubMed]

25. Thevannan, A.; Mungroo, R.; Niu, C. Biosorption of nickel with barley straw. Bioresour. Technol. 2010, 101, 1776-1780. [CrossRef]

26. Feng, N.; Guo, X.; Liang, S.; Zhu, Y.; Liu, J. Biosorption of heavy metals from aqueous solutions by chemically modified orange peel. J. Hazard. Mater 2011, 185, 49-54. [CrossRef]

27. Malkoc, E.; Nuhoglu, Y. Investigations of nickel(II) removal from aqueous solutions using tea factory waste. J. Hazard. Mater 2005, 127, 120-128. [CrossRef] 